\title{
HUNTING FOR "JeDI" SPINELS IN MOGOK
}

\author{
Vincent Pardieu
}

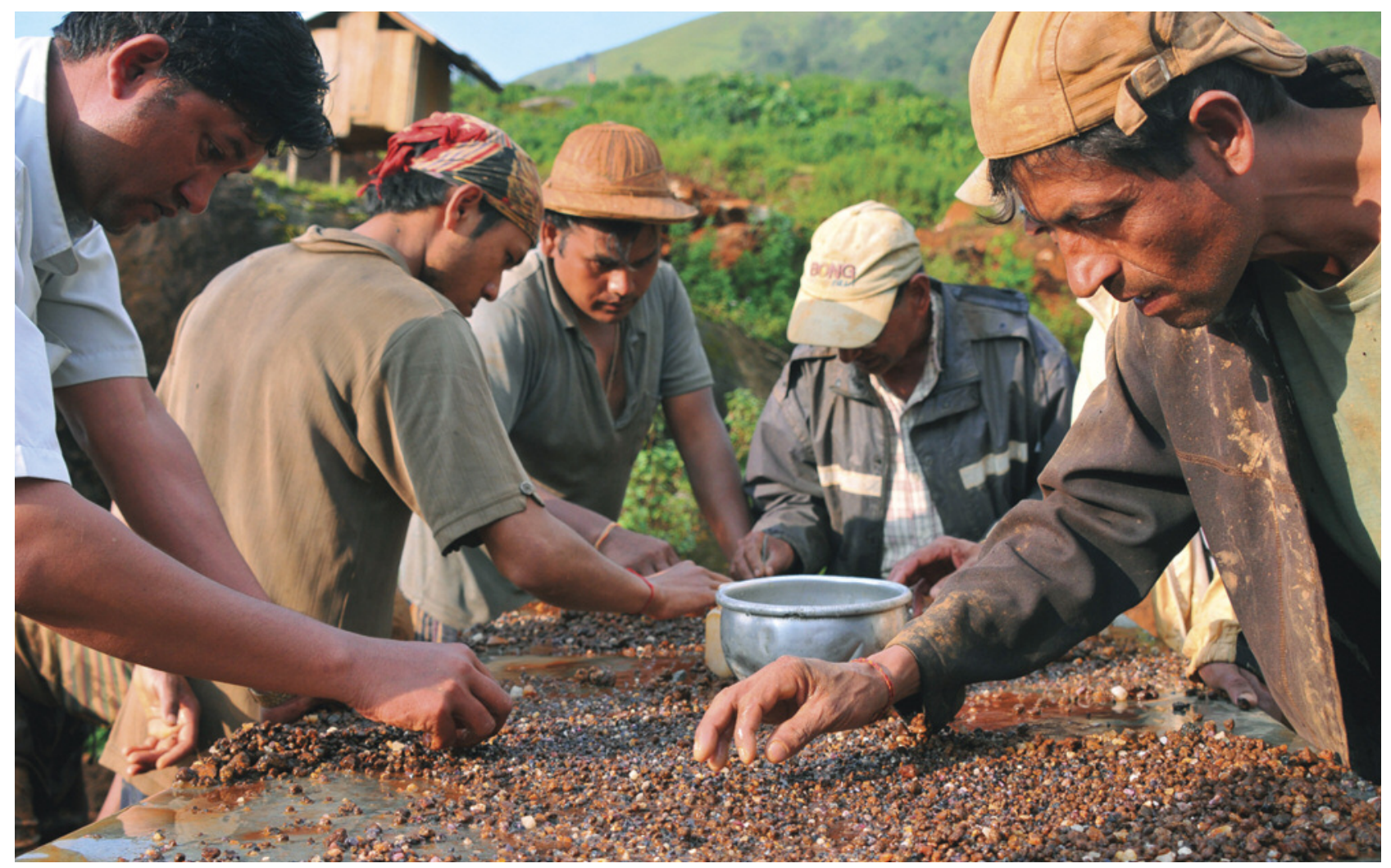

Miners collect spinels from gravel at the end of a long day at Man Sin. Photo by Vincent Pardieu, (C) GIA.

In the spring of 2001, I was studying gemology in Yangon, Myanmar, thanks to the support of $U$ Kyaw Thaung, a Burmese merchant from Mogok. It was a great period in my early life as a gemologist, living for several months with a Burmese gem trading family in an exotic country. One day, my host was visited by Hemi Englisher, a Bangkok-based gem dealer. When they finished business, Hemi asked me to join them, as he wanted to show me something special (figures 1 and 2). In his hand was something I had never seen: stunning little gems with a bright

See end of article for About the Author and Acknowledgments.

GeMs \& GemOlogr, Vol. 50, No. 1, pp. 46-57,

http://dx.doi.org/10.5741/GEMS.50.1.46.

(C) 2014 Gemological Institute of America neon pinkish red color, convincing me that spinels could equal rubies in beauty.

I asked if they were from Mogok, and the answer was equally surprising: No. They were from Namya, a ruby and spinel deposit located east of the jade mine at Hpakant in the Kachin state of Myanmar, where a gem rush had occurred in December 2000. I could hardly imagine then that a few months later I would follow Hemi to Namya for my very first field expedition. That adventure was truly a life-changing event (figure 3).

Over time, I started to have the feeling that these incredible little gems were somewhat lucky for me. In the spring of 2002, I landed my first job in the gem trade thanks to them. Henry Ho, a gem merchant from Bangkok and a spinel connoisseur, hired me with a simple mission: to find a bright $10 \mathrm{ct}$ spinel 


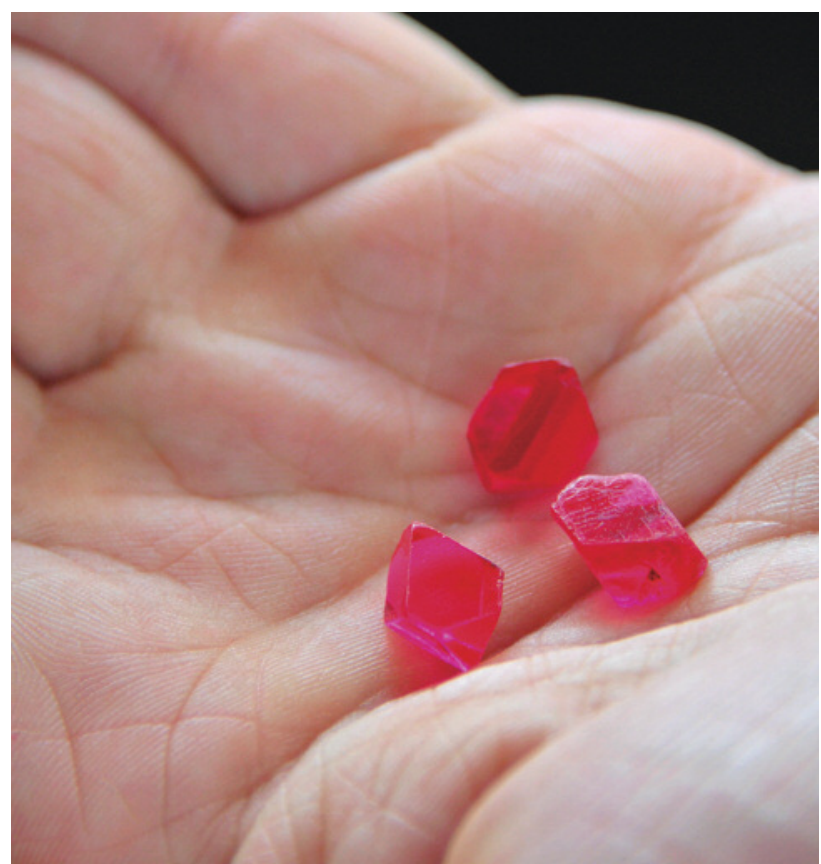

Figure 1. Fraicheur et delices (Cool and delicious): These bright neon red spinel crystals are from Man Sin, Mogok. Photo by Vincent Pardieu, (C GIA.

from Namya. We spent days together in Myanmar looking at gems. It was very different from my experience as a gemology student, as we were not focusing on gem identification but on quality and potential value. I learned that the typical downfall of an otherwise fine spinel was a dark tone, or "dark side," within the gem. At the time, the Hollywood blockbuster Star Wars: Episode II-Attack of the Clones was in theaters, and my motto became: "The

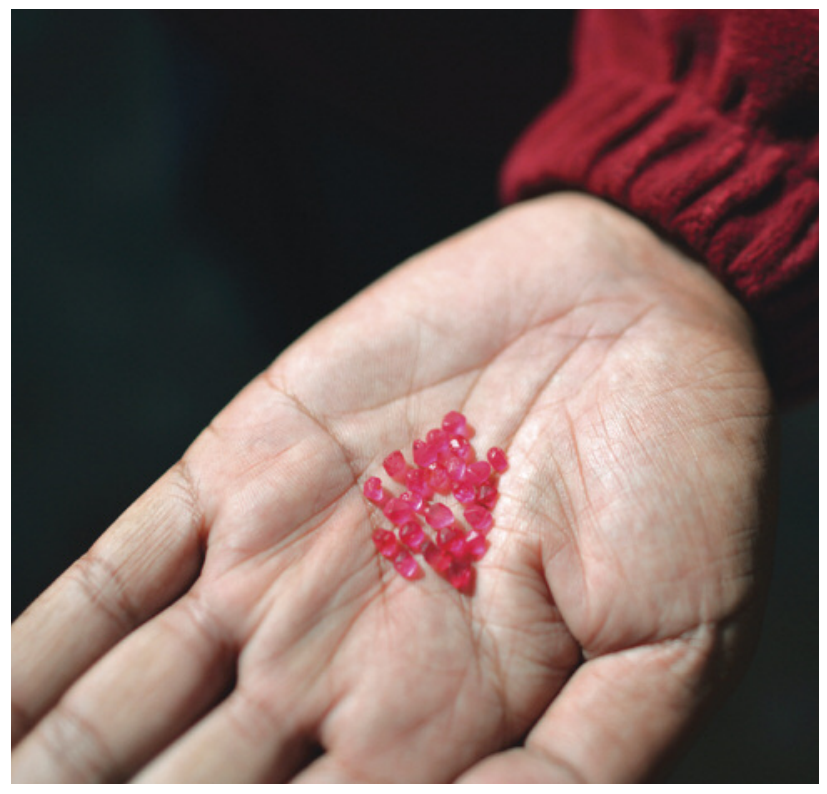

Figure 2. A parcel of fine spinel crystals from Namya similar to those the author saw in Yangon in 2001. Because Namya is a secondary deposit, most of its gems are more tumbled than typical stones from Mogok. Photo by Vincent Pardieu, (C) GIA.

Force is strong in spinel, but beware the dark side of the Force." Thus, we took to calling these glowing hot pink gems "Jedi" spinels, as they were untouched by the "dark side" (figure 4).

Like many, I believed for years that such "Jedi" spinels could only be found at Namya. Yet I was intrigued when some Burmese friends told me several times between 2001 and 2005 that such specimens were reportedly found from time to time around

Figure 3. Left: U Kyaw Thaung, the author, and Hemi Englisher in Yangon in February 2001, the day Hemi introduced the author to his first Namya spinels. Photo by Zin Mee Mee Lwin. Right: On the way to the Namya ruby and spinel mining area in 2001, the author enjoys his very first field expedition. As the deposit was located in a jungle-covered swamp, expedition leaders Hemi Englisher and Ted Themelis traveled by elephant while the author and the native guides walked in the swamp. Photo by an anonymous Burmese soldier, courtesy of the author.
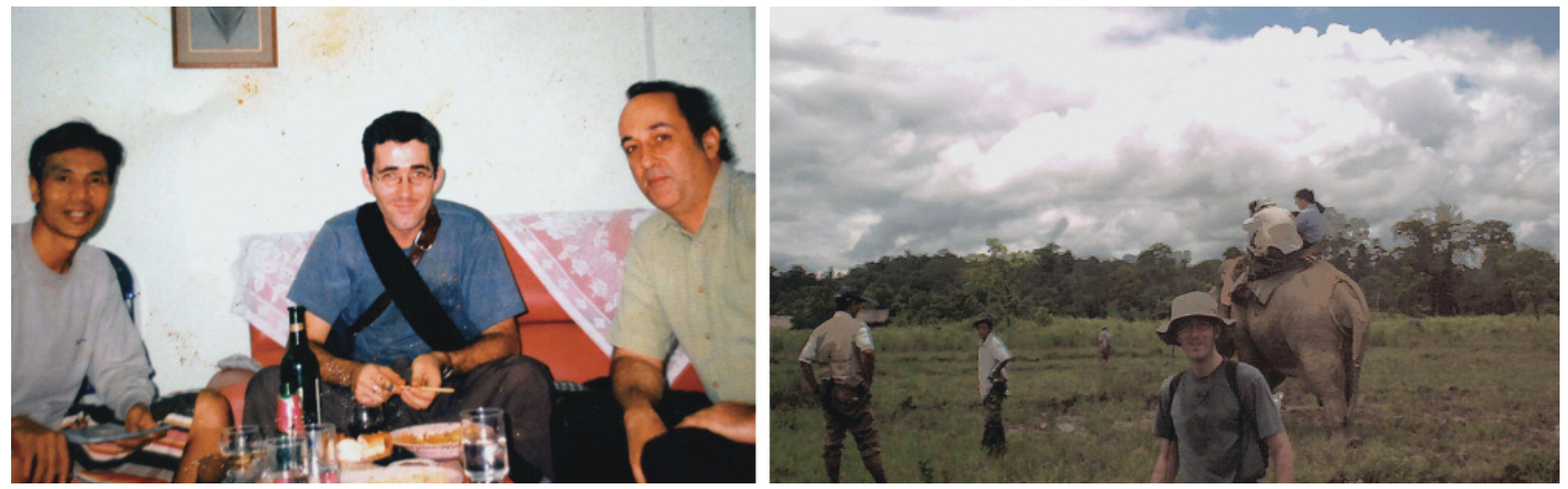


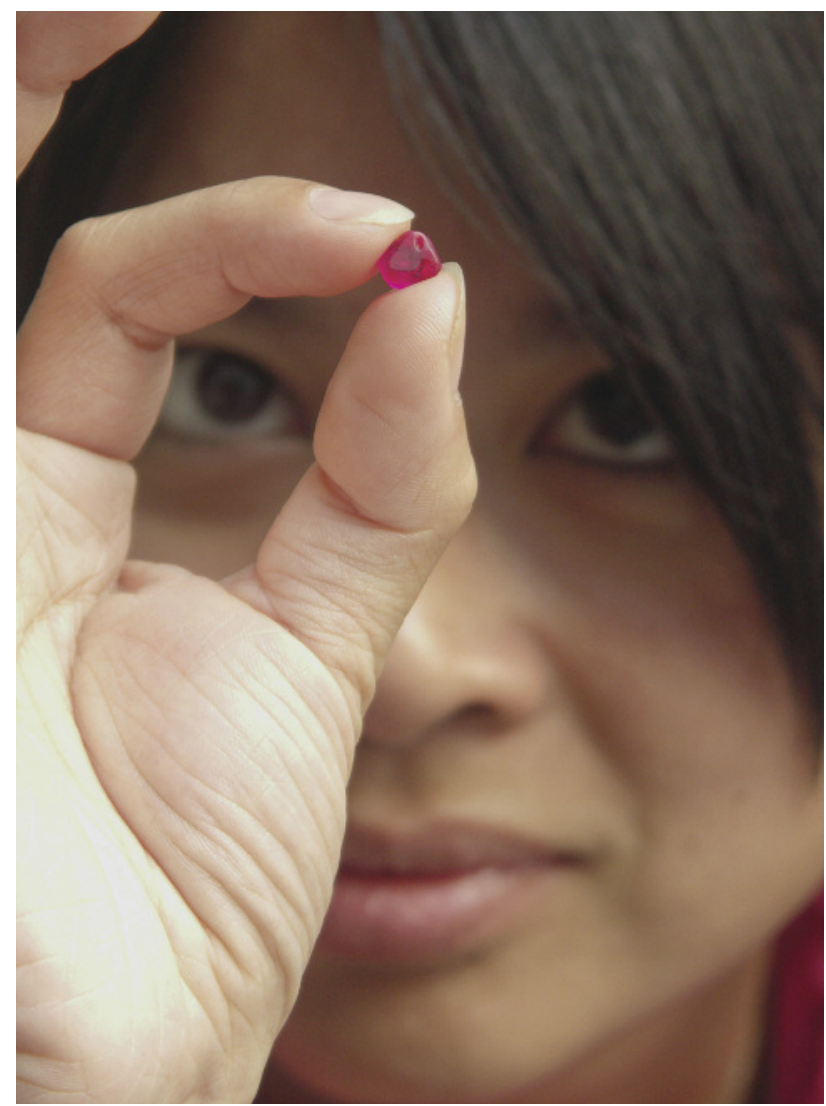

Figure 4. Hai An Nguyen Bui looks into a bright neon red spinel crystal, reportedly from Namya, while visiting Yangon in December 2006. Note the tumbled aspect typical of spinel from secondary deposits such as Namya. Photo by Vincent Pardieu/AIGS.

Mogok. These stones were usually sold as Namya spinels to get better prices. Was it just a rumor? Finding out proved to be difficult. The so-called Namya spinels were incredibly rare and in very high demand.

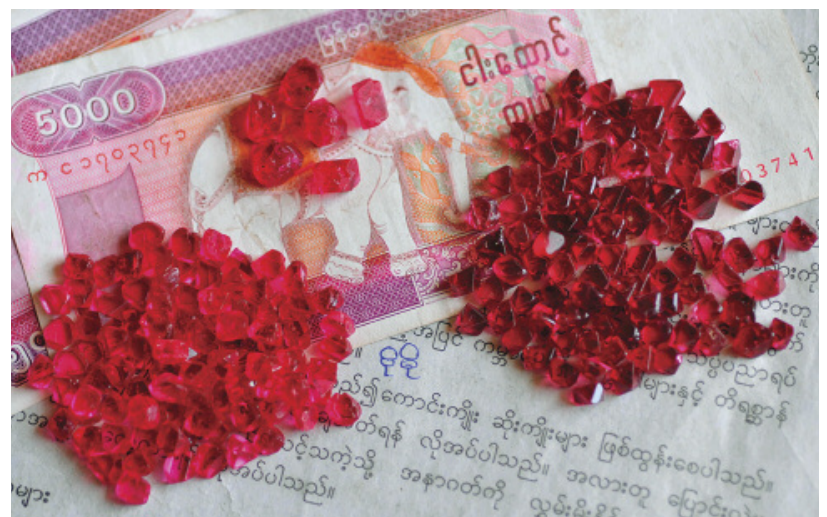

Figure 5. These parcels consist of bright neon red spinels from Man Sin (left) and classic red Mogok spinels (right). Note the unmistakable difference in tone and saturation between the two parcels. Photo by Vincent Pardieu, (c) GIA.

Despite my efforts, I was unable to find any evidence that Mogok had produced any spinel as bright as those from Namya (figures 5 and 6). Even if the rumors were true, calling them "Namya" spinel might prove controversial. (Consider the longstanding dispute in the gem trade over the origin-related term "Paraíba" to describe exceptionally vivid tourmaline, not only from Brazil, but also Mozambique and Nigeria.) Besides, "Jedi" spinel was fun and had a nice sound.

\section{RED SPINEL AND ITS SOURCES}

Historically, most red spinel comes from four remote places (Pardieu, 2008). From oldest to newest source, they are:

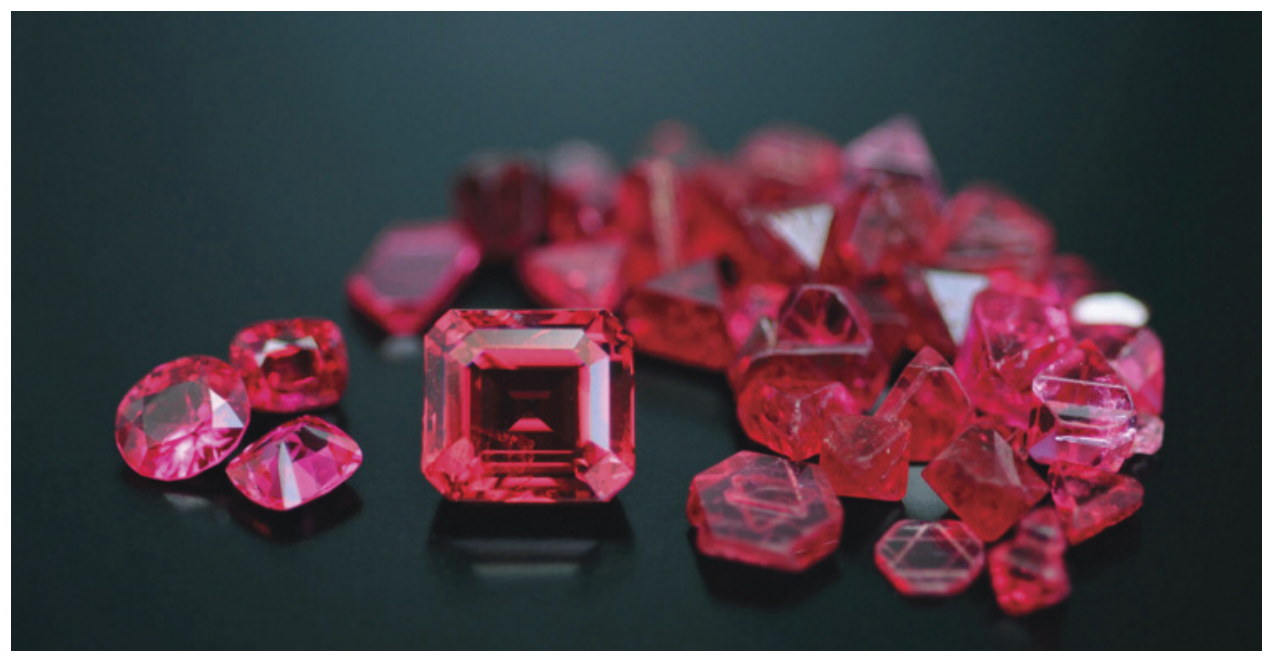

Figure 6. Classic rough and faceted red spinels from Mogok. The faceted stone, a fine red spinel weighing more than $5 \mathrm{ct}$, was purchased in the 1940s by Dr. Edward Gübelin. The crystals in the background are from the author's collection. Photo by Vincent Pardieu, courtesy of Gübelin Gem Lab. 
1) Badakhshan: This region is located between Afghanistan and Tajikistan, along the famed Silk Road. It has been a source of spinel since about the 10th century. According to locals, several deposits exist on both sides of the border, but the most famous mining site is near the Kul-i-Lal village on the Tajik side (Bowersox and Chamberlin, 1995; Bowersox, 2005; Hughes, 2006; Pardieu, 2006).

2) Myanmar (formerly Burma): Spinel has been found in both the Mogok Valley and the Namya area (Iyer, 1953; Gübelin, 1965; Keller, 1983; Kane and Kammerling, 1992; Themelis, 2000; Schlüssel, 2002; Themelis, 2008).

3) Vietnam: Red and blue spinel, along with ruby, was discovered in the Luc Yen district of northern Vietnam in 1988 (Long, 2013).

4) Tanzania: Red spinel was discovered near Mahenge and in the Uluguru Mountains of the Morogoro province in the late 1980s, and around Tunduru after 1994. The deposit near Mahenge became famous after the discovery of giant spinel crystals (up to $54 \mathrm{~kg}$ ) during the summer of 2007 (Keller, 1992; Pardieu, 2007; Weinberg, 2007; Hughes, 2011).

Over the past 12 years, I have collected samples from all these spinel deposits-as well as others in Pakistan, Kenya, Sri Lanka, and Madagascar-but none could match the saturation and brightness of the "Jedi" gems from Namya until very recently.

In 2011, Lou-Pierre Bryl, a gem merchant who travels regularly to Myanmar, repeated a rumor about a new spinel deposit in Mogok with material as bright as that from Namya. As Mogok was still not open to foreigners, we could not travel there to confirm the rumor.

In June 2013, Mogok was once again accessible to the outside world. I was unable to travel and asked Lou-Pierre, who was headed there, to inquire about this deposit. In August 2013, after three expeditions, Lou-Pierre confirmed the existence of a new spinel source in Man Sin. It was about a kilometer from Pyant Gyi and Pein Pyit (see figure 16), two areas known for producing beautiful spinels in the early 2000s, including some stunning "Star of David" macle crystals (figure 7). We decided to visit Mogok in September 2013, with a field trip to Man Sin as our main objective.

Any successful field expedition requires a good vehicle, the right permits, and the right local contacts. Within a few days, we contacted Jean-Yves

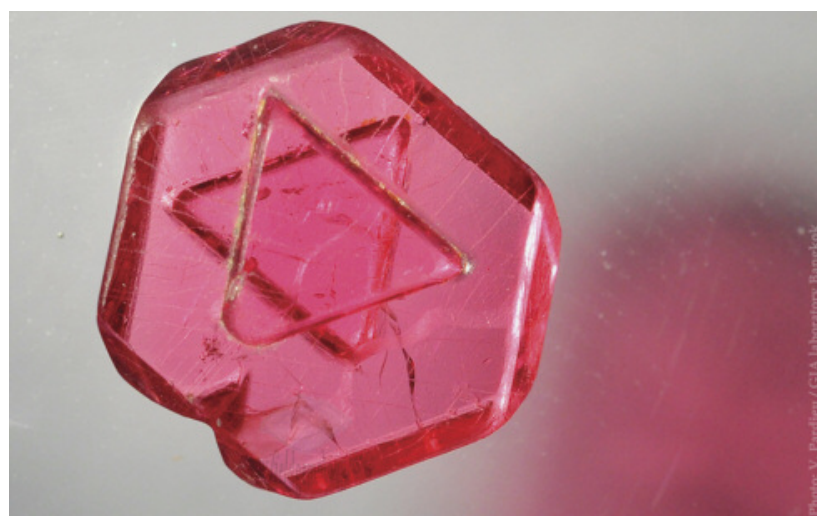

Figure 7. This fine "Star of David" spinel crystal is a macle, reportedly from the Pein Pyit/Pyant Gyi area east of Mogok, which was known for producing such crystals between 2000 and 2005. No processing, slicing, or polishing was performed on this specimen; it is $100 \%$ natural. Photo by Vincent Pardieu, (C GIA.

Branchard from Ananda Tours in Yangon to help us with permits and logistics. We also made arrangements with Jordan, who had been my driver, assistant, and translator during my previous time in Myanmar as a spinel buyer.

\section{AN INTRODUCTION TO MOGOK}

For gemologists and gem connoisseurs, Mogok (figure 8) must be experienced at least once in a lifetime. Gem mining likely began there more than a thou-

Figure 8. A classic view of Mogok town, dominated by the Chan Thar Gyi Pagoda (left) and arranged around its lake, which was created from a gem mine worked during British colonial times. Photo by Vincent Pardieu, (c) GIA.

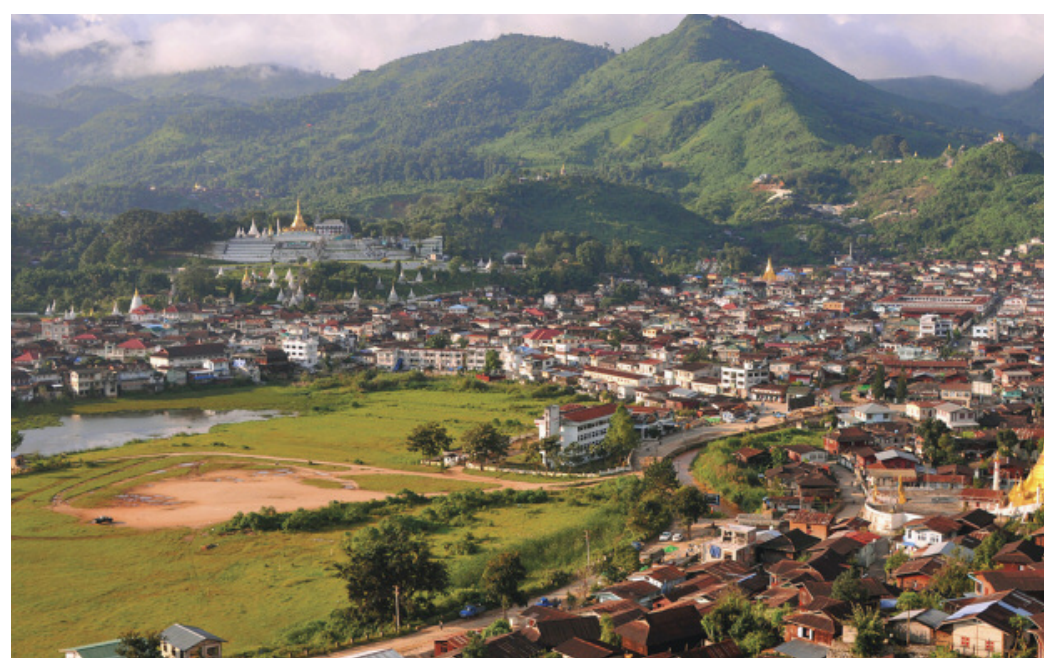




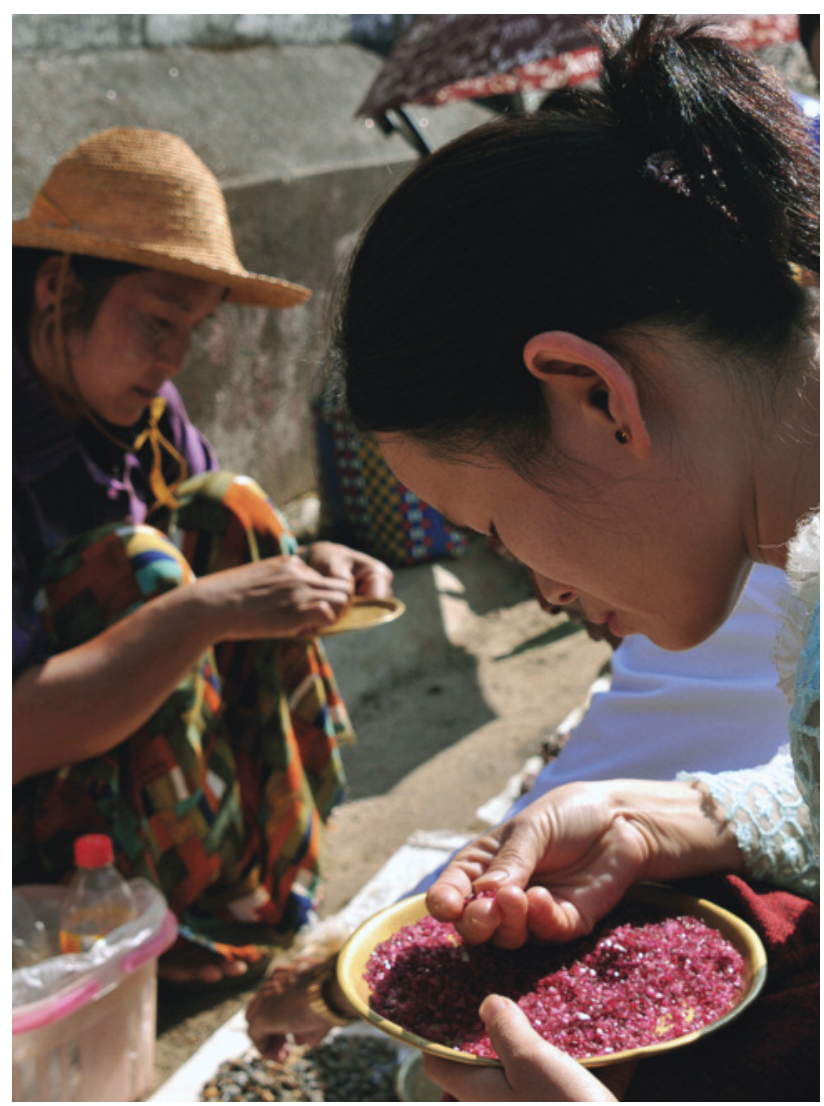

Figure 9. A Shan woman studies a parcel of spinel crystals at a gem market in Mogok. Photo by Vincent Pardieu, (C) GIA.

sand years ago, and no other area on Earth has produced so many exceptional rubies, sapphires, spinels, or peridots (Themelis, 2000; Schlüssel, 2002).

Mogok is the ultimate ruby land. Imagine a group of beautiful green valleys dominated by jungle-covered mountains, many of them topped by delicate pagodas. The twin cities of Mogok and Kyatpyin and the surrounding villages are still mainly comprised of wooden houses, giving them a quiet, romantic aspect.

Far removed from the modern ways of doing business using cell phones, airplanes, cars, and air-conditioned offices, the people of Mogok can be seen each day at the colorful gem and vegetable markets. Visitors will enjoy not only the diversity of gems produced around Mogok but also the diversity of its population: the Shan, Burmese, Nepalese, and Lissu are the main players in a rich and fascinating gem culture (figure 9).

\section{FRAICHEUR ET DELICES...}

For years, I referred to Burma as another world, as going there was like leaving the modern world to enter a place where time was of no concern. Even with modernity slowly making its way into Myanmar, the visitor spending a few days in Mogok still enjoys an experience truly from another time. In Mogok, I am reminded of Julius, a character from Joseph Kessel's novel La vallée des rubis (1955), who would say the words fraicheur et delices ("Cool and delicious") each time he looked at a fine gem or visited somewhere particularly interesting. Reading that novel as a child sparked my interest in Burma and gemstones. Each time I visit a place like Mogok and have the chance to encounter true beauty, these words come immediately to mind as a perfect way to describe this unique feeling and experience.

\section{ARRIVING IN MOGOK}

On September 19, 2013, Lou-Pierre and I took a morning flight from Bangkok to Mandalay. After exchanging some cash into Burmese kyat, we left for Mogok, using the new road past May Mio (also known as Pyin Oo Lwin) through the western part of Shan state. We reached Mogok around noon the next day.

After a typically quick Burmese lunch, we left for the Pan Shan gem market (figure 10) to meet U Ko James, a merchant specializing in spinel. I first met him in 2003, when he was on the rise. Nowadays he is an important man, and in Mogok many call him the "Spinel King." Mogok time passes slowly, but things went very quickly that day, as within a few minutes one of Ko James' contacts arrived with two small plastic baggies.

Fraicheur et delices, indeed. I had in my hand three stunning spinel crystals (figure 11), with deep, pure, highly saturated color and no dark tone. These were true "Jedi" spinels. But there was something more to the story: Unlike the rounded spinels I used to see from Namya, a secondary deposit, these were fine euhedral crystals with highly transparent faces. They had an incredible combination of crystal shape, color, and transparency. Forgive me for saying it, but they looked as good as synthetic spinel crystals. Gazing at them, I recalled the words of the great French merchant and explorer Jean-Baptiste Tavernier (1676) to describe exceptional transparency and crystallization of a gem: "fine water." These were perfect examples of "fine water" spinel crystals (figure 12).

On September 21, we started our day visiting the Cinema morning gem market. This market is usually stocked with low-quality stones, but it is still an interesting place to find out which deposits are active and what they are producing. 


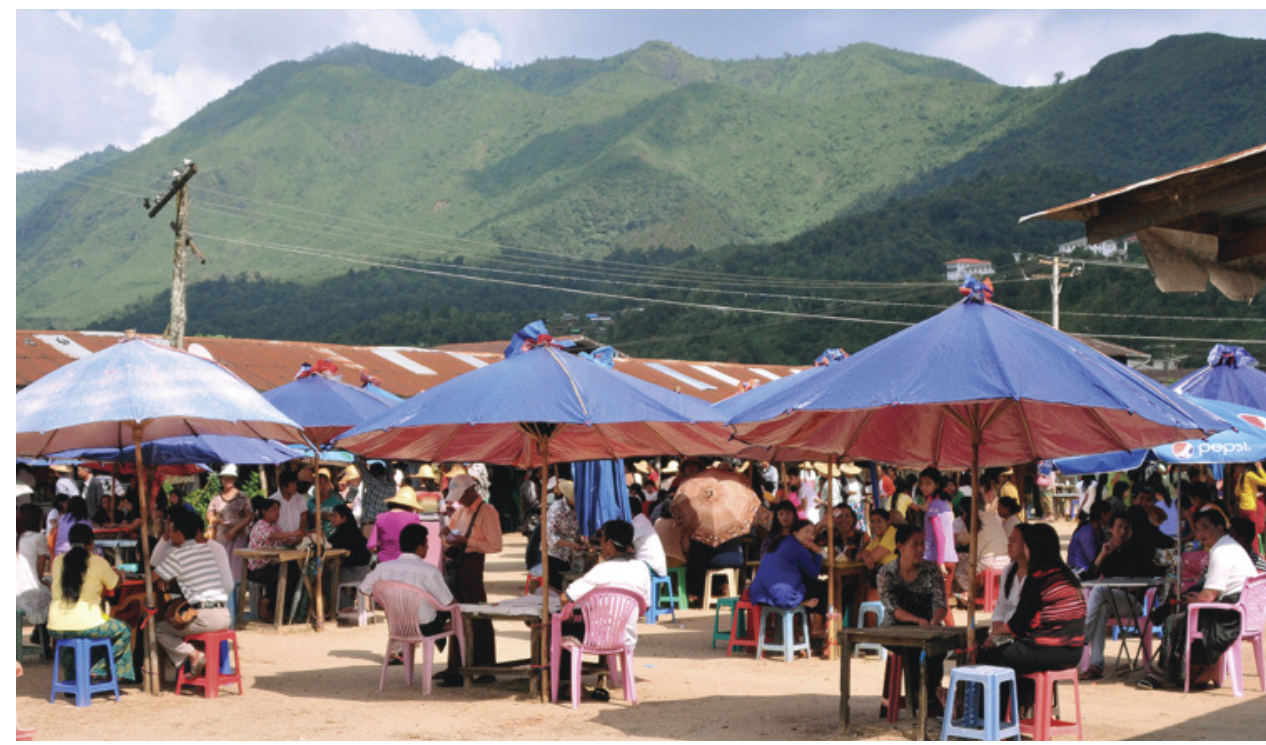

Figure 10. View of the Pan Shan afternoon gem market, where hundreds of traders gather each day. Photo by Vincent Pardieu, (C) GIA.

Next, we visited U Ko James (figure 13) at his home to talk about Mogok and see some special gems he was not willing to show at the market. He pointed out that between 2000 and 2005, the most

Figure 11. Lou-Pierre Bryl (right) shows what this expedition was all about: "Jedi" spinels from Man Sin. Photo by Vincent Pardieu, (c) GIA.

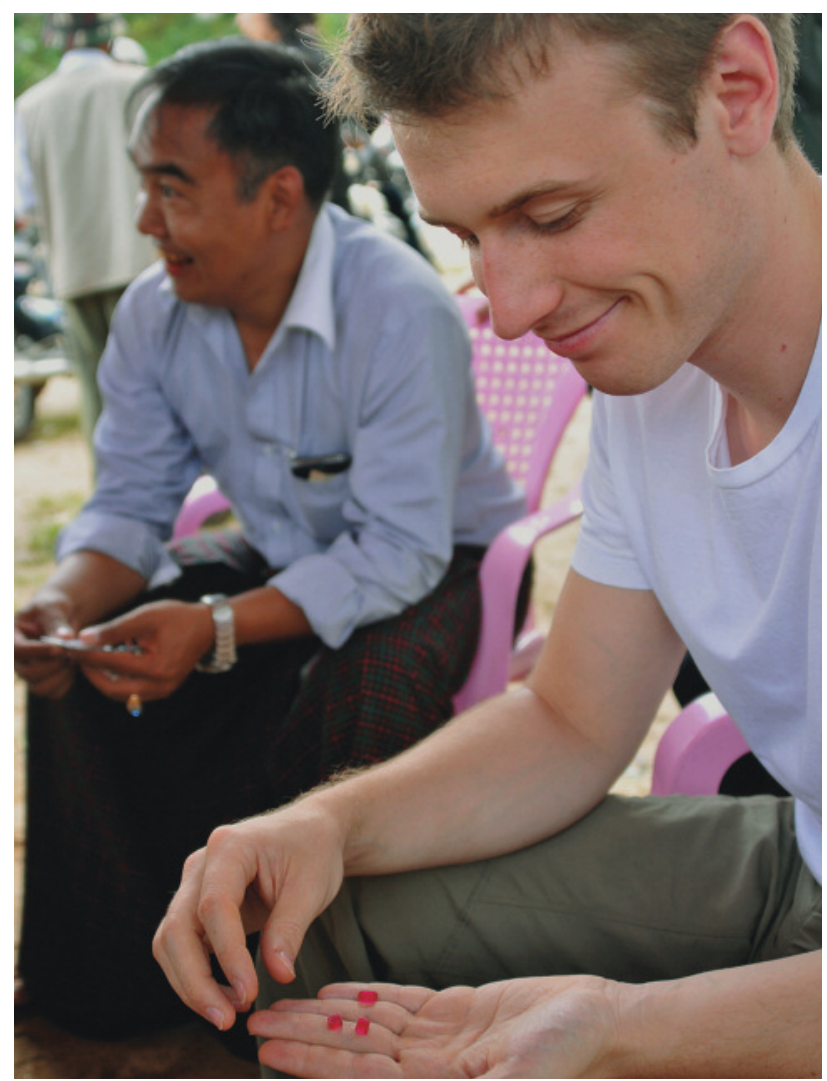

active spinel-mining area in Mogok was around Pyan Gyi and Pein Pyit. During that period, most of the bright neon material on the market came from the Namya area in Kachin state. But he confirmed that Mogok was also sporadically producing such gems. The area around Sakangyi probably supplied the best stones, followed by Shuant Pan. In 2006, some bright, highly fluorescent neon spinels emerged from Man Sin, and production peaked around 2009 with the discovery of a large pocket. Since then, production has been more sporadic. Overall, the stones from Man Sin were redder than those from Namya, which tend to be hot pink.

U Ko James said the largest fine spinel he had observed from Man Sin was a beautiful 35 ct rough stone, but it was not clean. Fine large gems were, and still are, extremely rare. Since 2006, he has seen

Figure 12. Details of the three fabulous spinel crystals seen at the gem market in Mogok. Photo by Vincent Pardieu, (C) GIA.

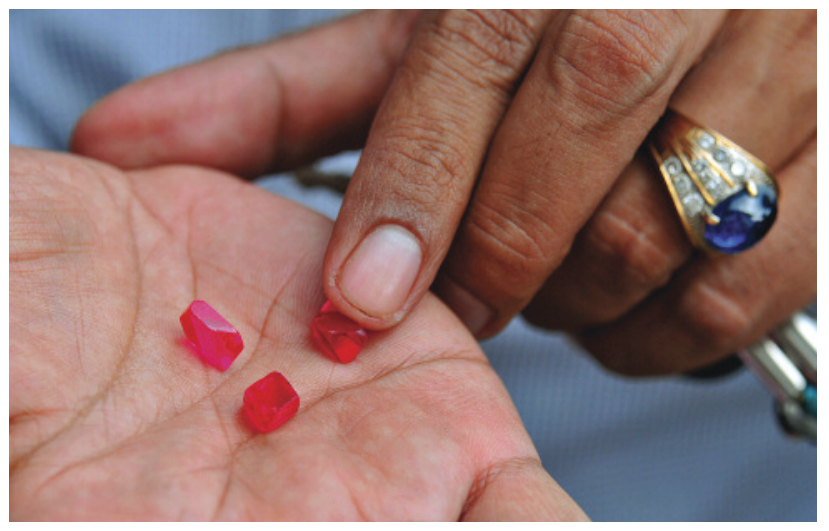




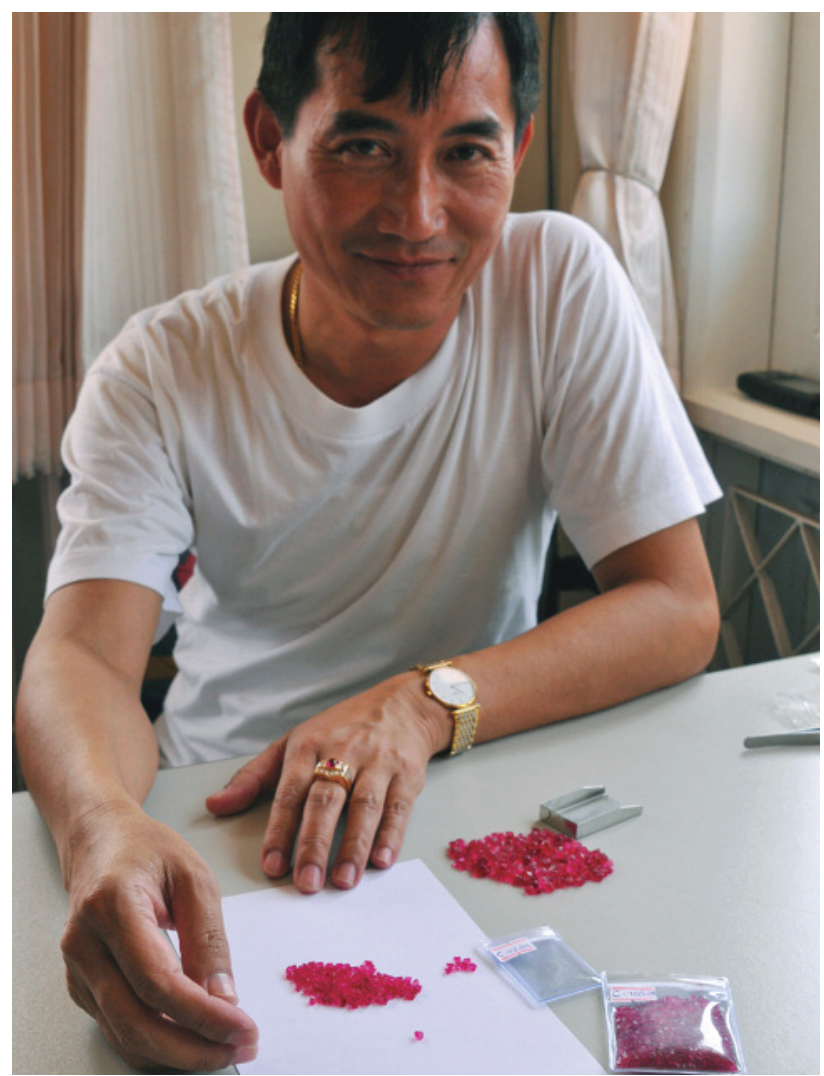

Figure 13. Going to the field is about three things: a place, its people, and its gems. U Ko James, known locally as the "Spinel King," displays some incredible parcels of bright red stones from Mogok. Photo by Vincent Pardieu, (C) GIA.

fewer than 10 fine rough stones over 20 ct /with "Jedi"-type color and clarity), and fewer than 100 stones over $10 \mathrm{ct}$. Most of the output consisted of

Figure 14. These fine, clean spinels are from Mogok. The neon pink one (left), just over $7 \mathrm{ct}$, was fluorescent and difficult to photograph. It is believed to have been mined at Man Sin. The $8 \mathrm{ct}$ stone (right) was especially stunning. Photo by Vincent Pardieu, (c) GIA.

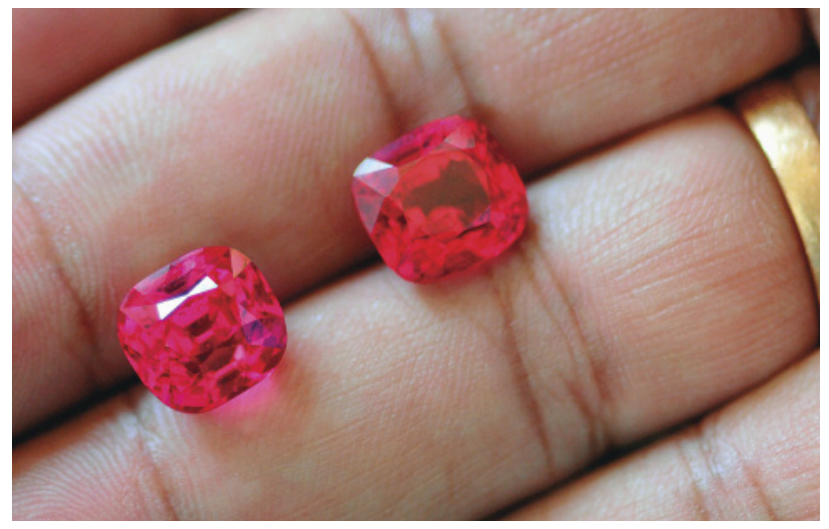

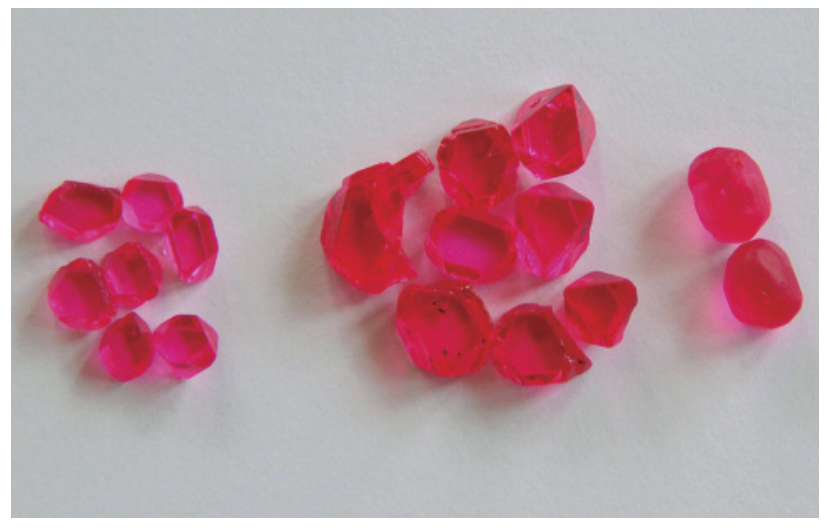

Figure 15. A selection of bright neon spinel crystals from Man Sin (left and center), alongside two spinel crystals from Namya (right). Note how the crystals from these two origins have a similar brightness; however, the two crystals from Namya are rounded, while those from Man Sin are sharp and well-formed. The larger crystals are about $1 \mathrm{ct}$ each. Photo by Vincent Pardieu, (C) GIA.

stones weighing less than $1 \mathrm{ct}$. He added that very few fine faceted gems over 10 ct have come from Man Sin. Fortunately, we were able to see two fine specimens (figure 14). One weighed slightly more than 8 ct (reportedly from Man Sin, though U Ko James could not guarantee its origin); the other, a bit more pink, was a $7 \mathrm{ct}$ stone that he said was from Man Sin. Perhaps my opinion was influenced by my enjoyment of Mogok, but when these stones appeared before my eyes, they were the most beautiful spinels I had ever seen.

While spinel from Namya once fetched premium prices, U Ko James told us that Man Sin's gems now draw the highest prices in the Burmese market. This is not based on reputation, as Man Sin still does not have Namya's name recognition, but on these fine spinels being redder and larger, with the same neon brightness due to a similar high saturation associated with a minimal tone (figure 15).

At the end of that wonderfully educational morning, we were able to buy a few interesting spinel samples, reportedly from both Man Sin and Namya, from U Ko James. After our purchase, we left for Man Sin.

\section{A VISIT TO THE MAN SIN SPINEL MINES}

Man Sin, which means "clear mirror" in Burmese, is a karstic area, meaning that the landscape has been formed by the dissolution of soluble rocks such as limestone and dolomite. It is located at $22^{\circ} 58^{\prime} 18^{\prime \prime} \mathrm{N}$ and $96^{\circ} 32^{\prime} 32^{\prime \prime} \mathrm{E}$ (figure 16), surrounded by Ta Yan Show to the southwest, Pyan Gyi/Pein Pyit to the 


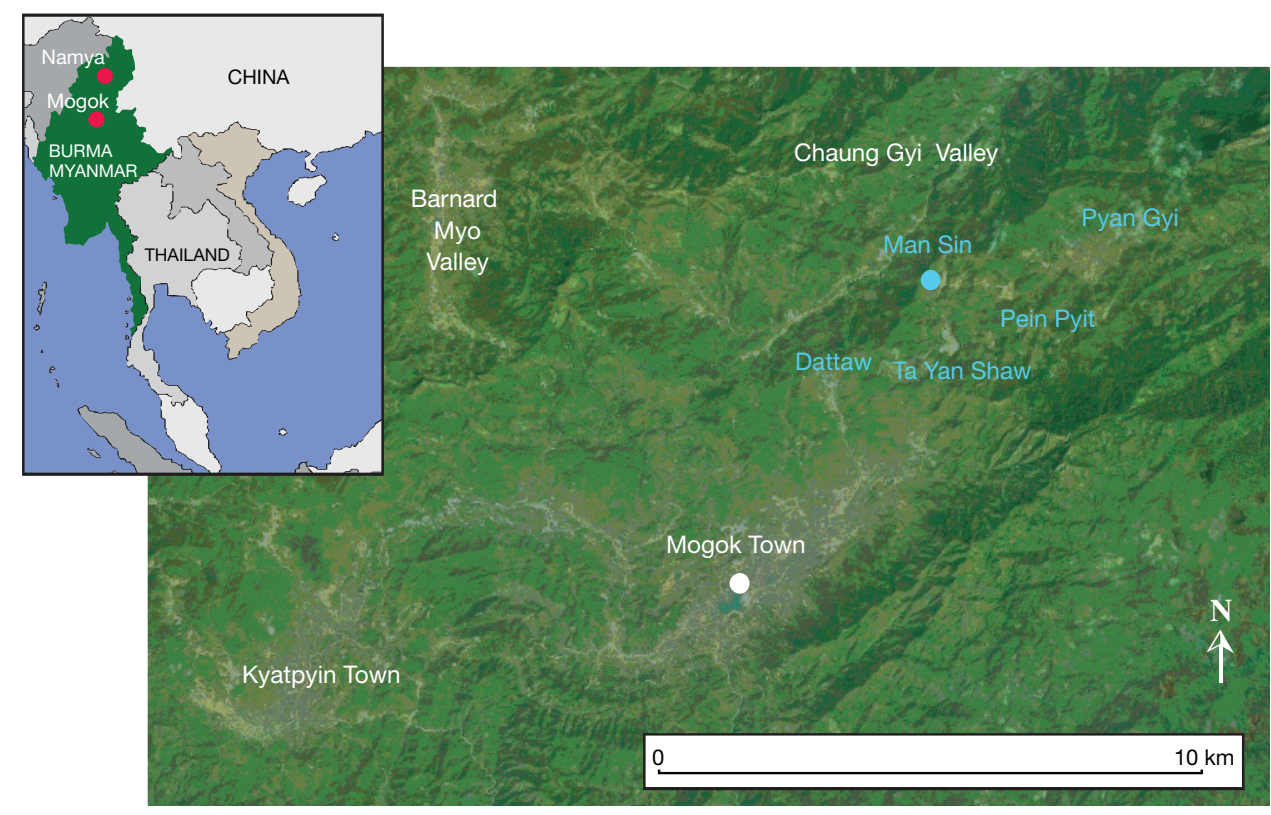

Figure 16. This map of Mogok (modified from Google Earth) shows the Man Sin spinel mining area, surrounded by other famous gem sites such as Dattaw, Ta Yan Shaw, Pein Pyit, and Pyan Gyi.

east, and the Chaung Gyi Valley to the north. In Man Sin, Nepalese farmers grow vegetables, mustard, and wheat. When we visited, three mining areas were producing mainly rubies. Another site, worked by two brothers of Nepalese origin named U Si Tu and U Kyaw Thu, yielded spinel (figure 17).

Interestingly, the miners at Man Sin are not searching for byon, the Burmese term for the gem-rich gravels found around Mogok and Kyatpyin. In the narrow
V-shaped valley at Man Sin, the erosion process is recent, and spinel can be found anywhere in the soil. The miners simply wash everything they collect from top to bottom. I witnessed a similar type of deposit at the spinel mines near Mahenge in Tanzania, which are also located in a narrow karstic valley.

At Man Sin, the operation managed by the two Nepalese brothers is relatively small. About 20 people operate an excavator, a few water cannons, and

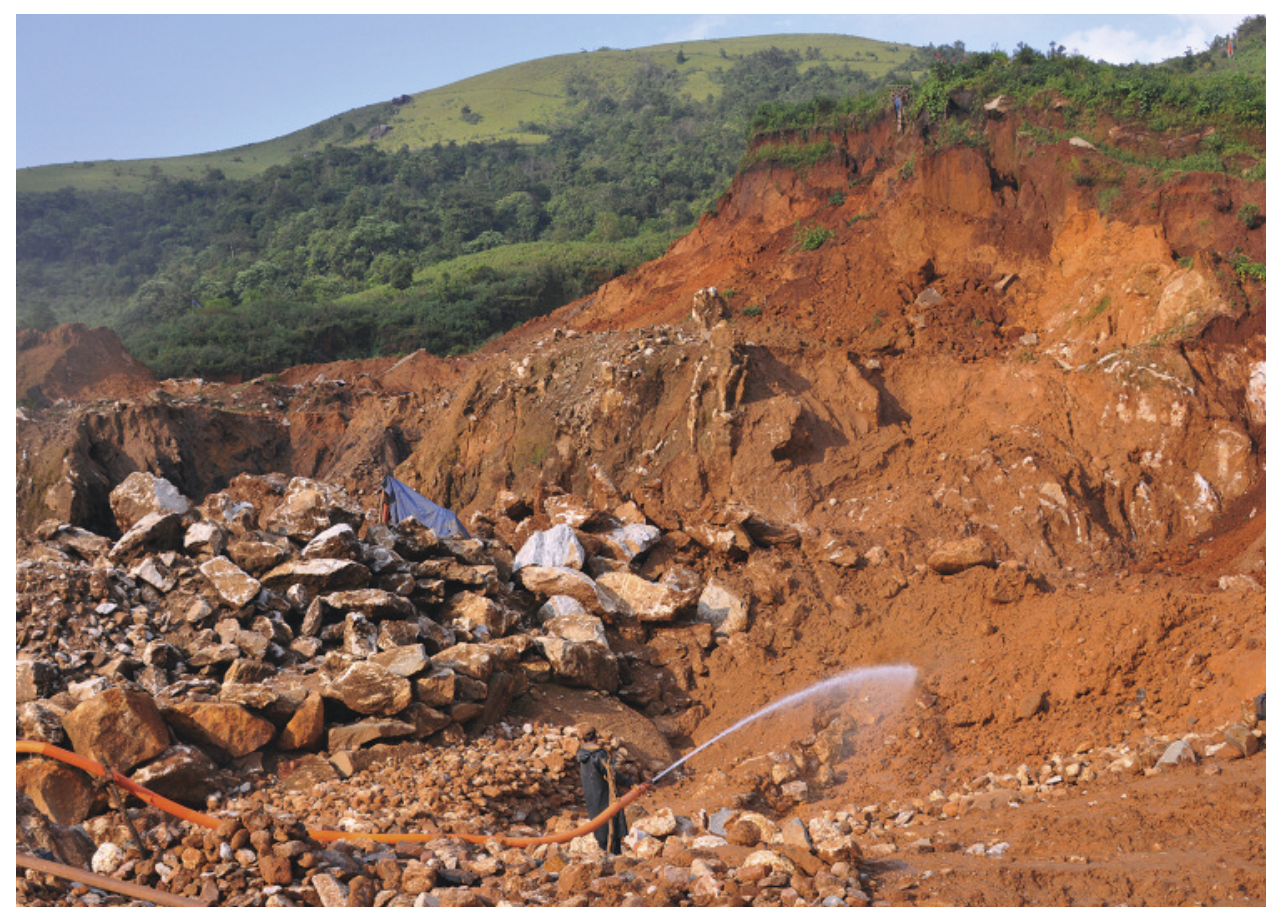

Figure 17. Spinel mining at Man Sin. The gems are unearthed by washing the ground in this karst-type geologic environment. On the other side of the hill, to the north, is the Chaung Gyi Valley. Photo by Vincent Pardieu, (C) GIA. 


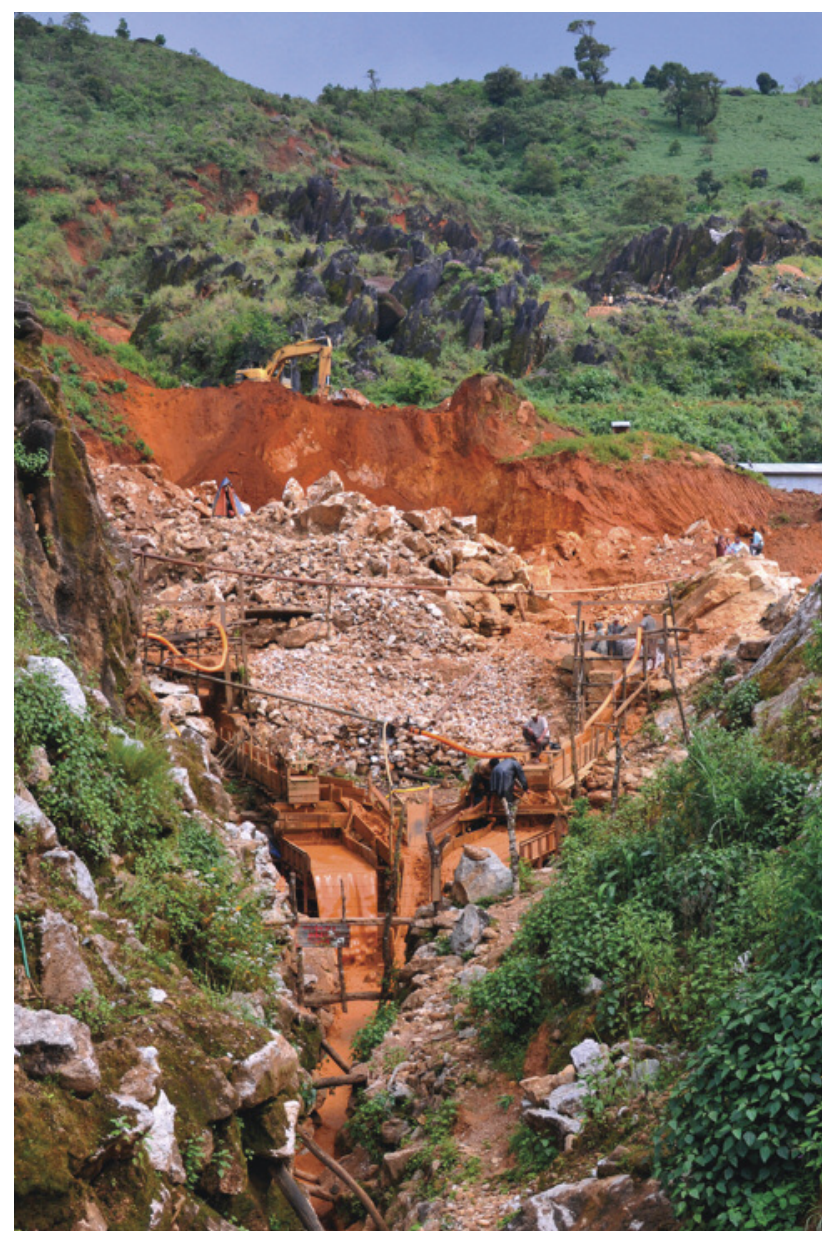

Figure 18. Overview of the spinel mining operation at Man Sin, where 20 workers operate an excavator, water cannons, and two washing plants. Photo by Vincent Pardieu, (C) GIA.

two washing plants (see lead photo and figure 18). Some of the workers earn a salary, while others own a share of the mine. The brothers, who told us they started production about 12 years ago, must renew their mining license every three years through Myanmar Gem Enterprises (MGE). They found their first pocket of "Jedi" spinels in 2009. Their first significant production consisted of several kilos of small, bright red crystals in their jig. It was an incredible sight, as the entire jig was reportedly filled with "wet" fluorescent red crystals glowing like embers in the evening light. Since then, output has been irregular. Sometimes a week passes by without any good yield, but then the next day they can find one or two kilos of fine gems in their jig. As they put it, "You may find a thousand fine gems, or nothing at all."

We also learned that only the northern part of this mine, close to the Chaung Gyi Valley, regularly produces fine spinel of the "Jedi" kind; the southern area, close to the other operations in Man Sin, primarily yields ruby. In the eastern part, most of the spinels are reportedly of the classic red type found in Mogok, possessing a higher, darker tone than "Jedi" spinels (figure 19).

While observing operations that day, we saw that the miners were able to find a few bright "Jedi"-type spinel crystals associated with some small rubies, some green tourmaline, and many spinels featuring a dark purple core and a shallow blue surface. As all the shareholders were not present during our visit, we could not immediately acquire any of the fine spinel mined that day. To obtain samples, we were told to visit U Kyaw Thu and his family at their home the next day. We did obtain a few small, bright red spinels for the GIA reference collection from a kanase woman who was mining the rejects under the jig.

That night we returned to Mogok with the miners. The following day, we visited the brothers and their family (figure 20). There we had tea and studied

Figure 19. U Si Thu examines a spinel crystal he found at Man Sin. If the stone appears somewhat ordinary at first sight, even experienced spinel miners know that such pockets can also host high-value gem material. Photo by Vincent Pardieu, (C) GIA.

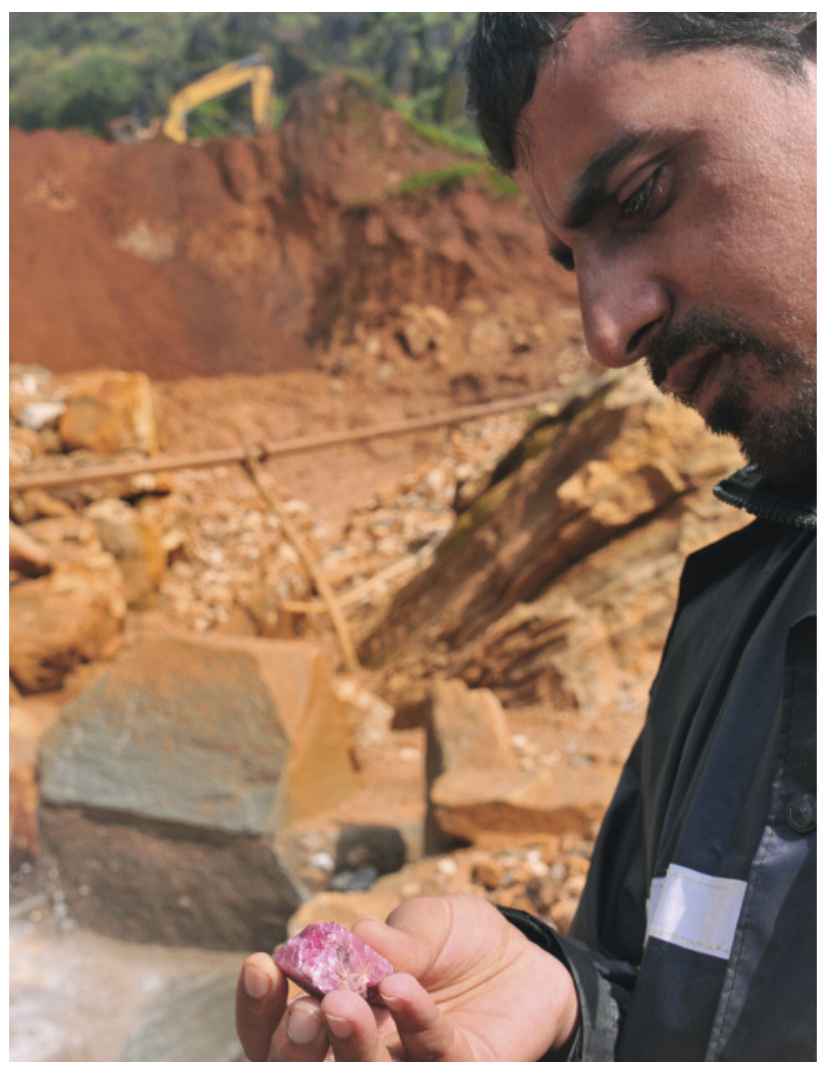




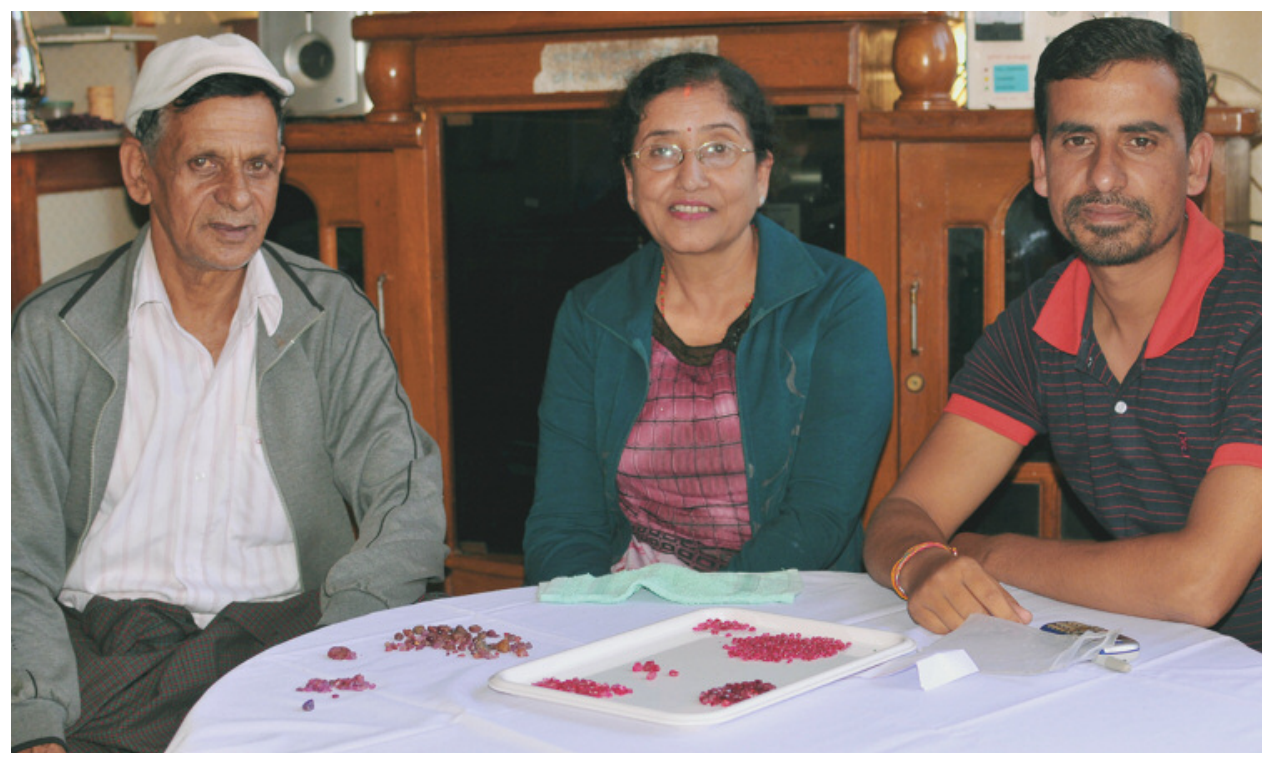

Figure 20. There are no gems without gem people. U Si Thu (right) and his parents show some fine spinels from the mine at Man Sin. Photo by Vincent Pardieu, (C) GIA.

some of the stones from their recent production, acquiring additional samples for the GIA reference collection. Not surprisingly, most of the stones we saw either at the mine, from the miners' stock, at the gem market, or from U Ko James' stock barely showed evidence of weathering. This is very different from the spinel crystals found in Namya, which are usually quite tumbled. We were also told that no one has found "Jedi" spinel in matrix. Regarding size and quality, the miners said the best stones they ever found were two perfect crystals of about 5 ct each, much smaller than what U Ko James reported (figure 21). I often remember the words of Dr. Saw Naung

Figure 21. Fine "Tedi" spinels from Man Sin. The seven faceted stones on the left have a total weight of $12.9 \mathrm{ct}$, while the two clean crystals weigh 3.9 and $3.3 \mathrm{ct}$. Photo by Vincent Pardieu, (C) GIA.

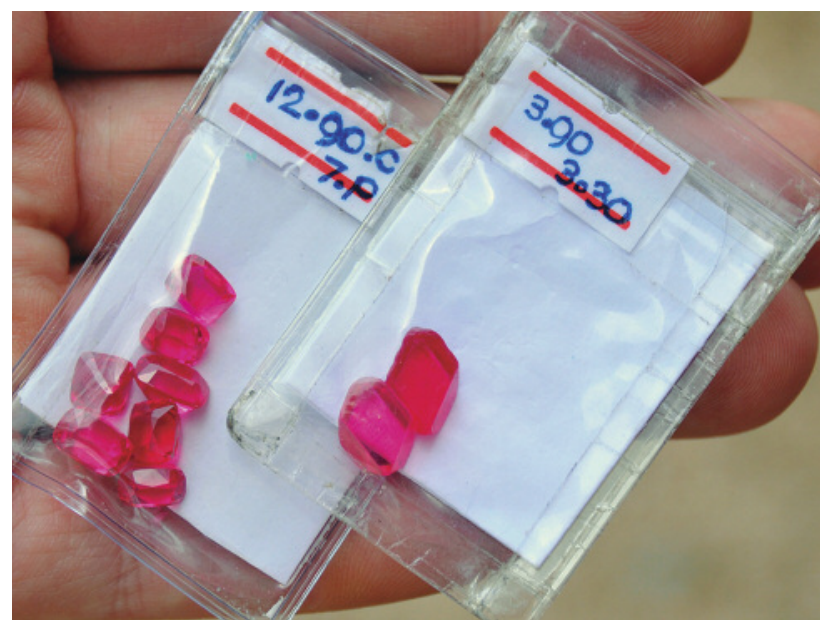

Oo, a Burmese miner who helped me during my different visits to Mogok between 2001 and 2004: He once told me that in Mogok, the miners keep secrets while the traders tell stories. Hearsay is one of the main challenges faced by gemologists-and not only in the field. Indeed, lab gemologists should rely more on their eyes than their ears.

Upon my return to Bangkok, the team at GIA's lab studied the samples. Notably, the stones from these three different sources shared some distinguishing features not often found in spinel from other sources, such as multiphase orange inclusions (figure 22) where diaspore, pyrite, sulfur, and

Figure 22. The samples obtained during the trip to Man Sin exhibited characteristics, such as this orange multiphase inclusion, that are not normally associated with spinel from other sources. Photomicrograph by Jonathan Muyal, magnified 100x.

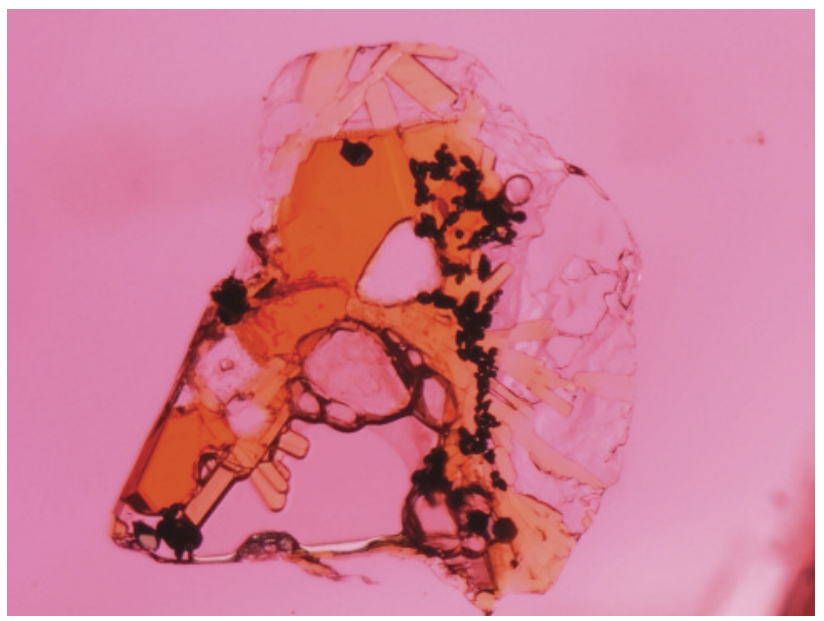


dolomite (as identified by Raman) were found to be associated together. Furthermore, chemical analysis yielded two intriguing discoveries. First, the stones that were collected from the kanase woman at the mine, from the private home of the Nepalese brothers, and from U Ko James had a similar chemical composition at the trace-element level. This "fingerprint" was quite different from the samples obtained during field expeditions to any other spinel deposit around the world. This indicates that chemical composition may become a very useful tool for determining the origin of spinel. Second, the "Jedi" spinel from both Man Sin and Namya have very low iron content when compared with spinel from Mogok, Vietnam, Tanzania, and Tajikistan and with "nonJedi" spinel from other mining sites in Mogok. In both red and blue spinel, the high tone seems to be explained by the presence of iron, while red spinel owes its color to the presence of chromium.

The separation of Man Sin spinel from those produced at Namya or other sites may be aided by the data collection we are currently developing from analyses of data collected from stones at other deposits. Determining what is actually coming out of Man Sin in terms of size and quality will not be easy, but the samples our field expedition team (figure 23) collected from the three independent sources will help our gemologists characterize this deposit. Such systematic collection is necessary in order for labs to reliably explore the origin determination of spinel. GIA's Bangkok laboratory is currently preparing an

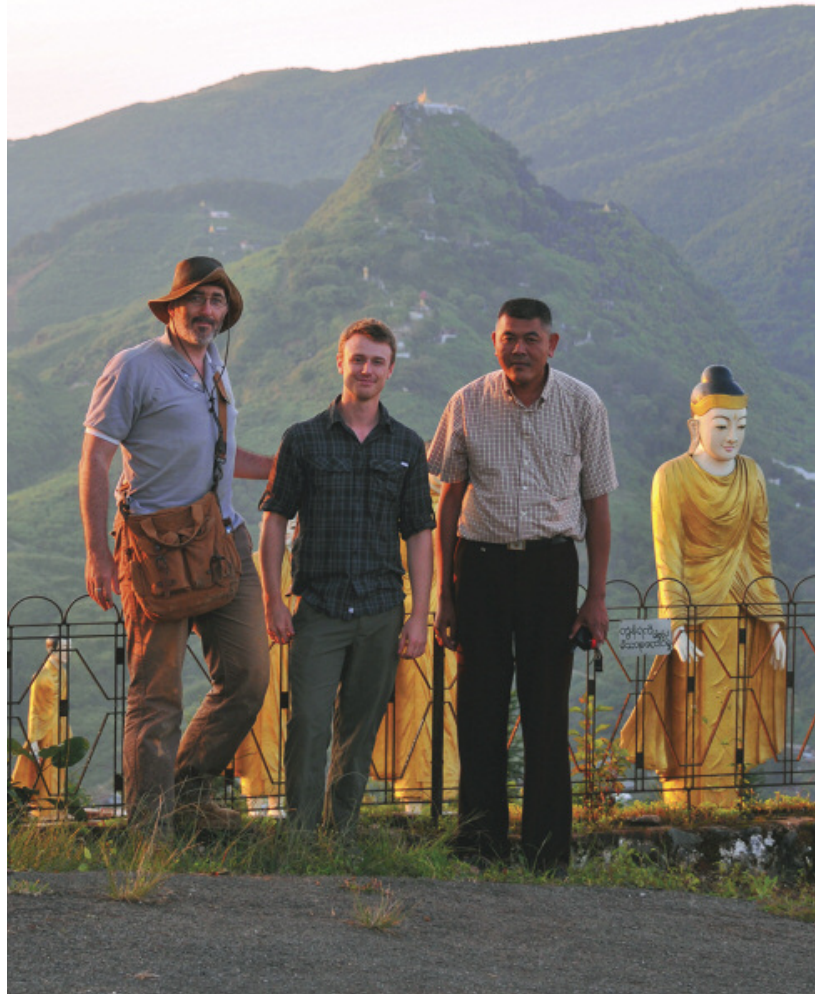

Figure 23. The GIA field expedition team poses at Daw Nan Gyi Hill, in front of Pingu Thaung Mountain. From left to right: the author, Lou-Pierre Bryl, and Jordan, our friend and driver from Mogok. Photo by U Wanna, (C) GIA.

in-depth study of these incredible little gems for future publication.

\section{ABOUT THE AUTHOR}

Vincent Pardieu (vpardieu@gia.edu) is senior manager of field gemology at GIA's Bangkok laboratory. He has visited the Mogok region nine times since 1998.

\section{ACKNOWLEDGMENTS}

Special thanks to Lou-Pierre Bryl and Jean Baptiste Senoble (Senoble \& Bryl, Geneva); Jean-Yves Branchard and his staff at Ananda Travels in Yangon; my friend Jordan; and the gem people of Mogok - particularly U Ko James, U Si Thu, and U Kyaw Thu for their help during the expedition.

I would like also to express my gratitude to Richard W.

Hughes, Laurent Massi, and Mikola Kukharuk from Nomads;

Vitaly Golokoz from Vitalit; Vlad Yavorskyy from Yavorskyy; Joe
Belmont from KV Gems; and William Larson from Pala Gems for our enthusiastic discussions about Burmese spinels, and for graciously educating me and showing me some of their most fascinating gems.

I would like to express my gratitude to U Kyaw Thaung, Hemi Englisher, and Henry Ho for initiating me and fueling my interest in spinels as a young gemologist finding his way in Myanmar, and to Dr. Saw Naung Oo for being the best guide I could have hoped for in Mogok from 2000 to 2004.

Finally, this article and expedition were possible thanks to the support of Ken Scarratt and the staff of GIA's laboratory in Bangkok. 


\section{REFERENCES}

Bowersox G. (2005) July-August, 2005 Hindu Kush/Pamir Mountains expedition. http://www.gems-afghan.com/cgi-bin/ aslides.pl? 12\&1.

Bowersox G.W., Chamberlin B. (1995) Gemstones of Afghanistan. Geoscience Press, Tucson, AZ.

Gübelin E.J. (1965) The ruby mines in Mogok in Burma. Journal of Gemmology, Vol. 9, No. 12, pp. 411-426.

Hughes R.W., Pardieu V., Soubiraa G., Rogers M., Chitty W., Chitty M., Brunot P. (2011) Downtown: Gem hunting in central \& southern Tanzania. http://www.ruby-sapphire.com/ tanzania-ruby-sapphire-spinel.htm, May 19.

Hughes R.W., Pardieu V., Soubiraa G., Schorr D. (2006) Moon over the Pamirs: Chasing ruby and spinel in Tajikistan. http://www.ruby-sapphire.com/tajikistan_ruby_and_spinel.htm, Sept. 25.

Iyer L.A.N. (1953). The geology and gem-stones of the Mogok Stone Tract, Burma. Memoirs, Geological Survey of India, Vol. $82,100 \mathrm{pp}$.

Kane R.E., Kammerling R.C. (1992) Status of ruby and sapphire mining in the Mogok Stone Tract. $G \uplus G$, Vol. 28, No. 3, pp. 152-174.

Keller P.C. (1983) The rubies of Burma: A review of the Mogok Stone Tract. Ge G, Vol. 19, No. 4, pp. 209-219.

Keller P.C. (1992) Gemstones of East Africa. Geoscience Press, Phoenix, AZ.

Kessel J. (1955) La vallée des rubis. Éditions Gallimard, Paris.

Long P.V., Pardieu V., Giuliani G. (2013) Update on gemstone mining in Luc Yen, Vietnam. GやG, Vol. 49, No. 4, pp. 233-245,
http://dx.doi.org/10.5741/GEMS.49.4.233.

Pardieu V. (2006) From Kashmir to Pamir, Summer 2006: Gemmological expedition report to ruby, emerald and spinel mining areas in Central Asia. Part 4: China (Xin Jiang): Emeralds from the silk road. http://www.fieldgemology.org/gemology $\% 20$ china $\% 20$ emerald $\% 20$ davdar.php.

Pardieu V. (2007) Tanzania, October 2007: A gemological safari, part 1: Ruby, sapphire, moonstone, spinels, tsavorite, alexandrite: Gems from central and south Tanzania. www.fieldgemology.org/ gemology $\% 20$ tanzania $\% 20$ ruby $\% 20$ sapphire $\% 20$ spinel $\% 20$ tsavorite $\% 20$ alexandrite $\% 20$ emerald $\% 20$ tunduru $\% 20$ songea $\% 20$ morogoro \% 20merelani.php.

Pardieu V., Hughes R.W., Boehm E. (2008) Spinel: Resurrection of a classic. InColor (Summer): pp. 10-18.

Schlüssel R. (2002) Mogok, Myanmar: Eine Reise durch Burma zu den schönsten Rubinen und Saphiren der Welt [Mogok, Myanmar: A Journey through Burma to the Sweetest Rubies and Sapphires in the World]. Christian-Weise Verlag, Munich.

Tavernier J.B. (1676) Les Six Voyages de Jean Baptiste Tavernier. Paris.

Themelis T. (2000) Mogok: Valley of Rubies «) Sapphires. Published by the author, Bangkok.

Themelis T. (2008) Gems ↔) Mines of Mogok. Published by the author, Bangkok.

Weinberg D. (2007) Giant red spinel crystal discovered in East Africa. http://www.multicolour.com/spinel/giant-red-spinelcrystal-discovered-in-east-africa.html, Oct. 5. 